\title{
Measurement of Family Environment Levels among Students of Saveetha Dental College: Questionnaire Based Study
}

\author{
Harini. $\mathrm{K}^{1 *}$, Dr. Karpagam krishnamoorthy ${ }^{2}$
}

\section{ABSTRACT}

Aim: To measure the family environment levels among students in Saveetha dental college. Objective: Measuring the family environment scale by a questionnaire. Background: The family is the oldest and the most important of all the social institutions. The family environment is influenced by a number of factors like constellation, number of children in the family, marital relationship between husband and wife, maternal environment, socio-economic status and religious background of the family. Reason: I am interested to know about the family environment of students. This study also helps us to emphasise the values about family environment.

Keywords: Family environment, Adjustment, Behaviour.

The family is the oldest and the most important of all institutions that man has devised to regulate and integrate his behavior as he strives to satisfy his basic need.(7) Family members are very important factor influencing survival ,thus, strong emotional bonds evolved to faster long term commitment among parents, children and relatives. (3)Family environment continues to be a crucial importance throughout adolescence and young adulthood.(Vauwel,2000).The important of family relationship in personality development and adjustment has always been recognized in psychological studies.(5) The families in general and parents in particular, have often been deemed to be the most important support system available to the child.(2) There is a significant difference between male and female students who are in first and second birth order and third and above birth order on their family environment. There is no significant difference between joint family and nuclear family students on their family environment. (6)It has been found that children in unbroken families have a propensity to shoe the signs of better emotional psychological well-being and are less likely to exhibit behavioral problems. (4). It is important for the patients to arrange conducive family environment and to monitor their children's technological exposure from early years. That will certainly help in conditioning and shaping

\footnotetext{
${ }^{1}$ First year BDS, Department of Anatomy, Saveetha dental college and hospitals, Chennai, India

${ }^{2}$ Lecturer, Department of Anatomy, Saveetha dental college and hospitals, Chennai, India

*Responding Author (C) 2016 I K Harini, K Krishnamoorthy; licensee IJIP. This is an Open Access Research distributed under the terms of the Creative Commons Attribution License (http://creativecommons.org/licenses/by/2.0), which permits unrestricted use, distribution, and reproduction in any Medium, provided the original work is properly cited.
} 


\section{Measurement of Family Environment Levels among Students of Saveetha Dental College: Questionnaire Based Study}

children's behavior in right direction. (1)The perception of family environment is significant predictor of depression among adolescents ; family disorganization, conflict, and lack of control, lack of cohesion and expressiveness have been observed as common factors in family backgrounds of children who develop depression.(8)

\section{MATERIALS AND METHODS}

A questionnaire consisting of 20 question which measures the family environment level of students were prepared. It was distributed to randomly chosen 52 students (23 male and 29 female) who were studying in Saveetha dental college. This questionnaire consists of 18 positively worded and 2 negatively worded questions. The positive and negative questions are mixed randomly in the questionnaire. The questionnaire is a 3 point scale type. The three points are "ALWAYS", "SOMETIMES" and "NOT AT ALL". The weight system for these response categories are 3, 2, 1 respectively for positively worded items and 1, 2, 3 for the negatively worded items. The score between 20-33 were considered as unhealthy family environment level, the score between 34-47 were considered as moderate family environment level and the score between 48-60 were considered as healthy family environment level. The participants were seated comfortably and the questionnaire was given to them. Then the following instructions were given. Answering the questions accurately requires honest reflection on how you were treated by parents and their involvement in studies, hobbies and other activities etc.

\section{RESULTS}

Family Environment Score Of Each Subject

\begin{tabular}{|l|l|l|}
\hline S.NO & GENDER & SCORE \\
\hline 1 & F & 43 \\
\hline 2 & F & 44 \\
\hline 3 & F & 57 \\
\hline 4 & F & 40 \\
\hline 5 & F & 43 \\
\hline 6 & F & 58 \\
\hline 7 & M & 40 \\
\hline 8 & F & 60 \\
\hline 9 & F & 50 \\
\hline 10 & M & 51 \\
\hline 11 & F & 52 \\
\hline 12 & M & 46 \\
\hline 13 & M & 47 \\
\hline 14 & M & 42 \\
\hline 15 & M & 47 \\
\hline 16 & F & 48 \\
\hline 17 & F & 52 \\
\hline 18 & F & 53 \\
\hline 19 & M & 51 \\
\hline
\end{tabular}


Measurement of Family Environment Levels among Students of Saveetha Dental College:

Questionnaire Based Study

\begin{tabular}{|c|c|c|}
\hline 20 & $\mathrm{M}$ & 55 \\
\hline 21 & $\mathrm{M}$ & 57 \\
\hline 22 & $F$ & 50 \\
\hline 23 & $\mathrm{~F}$ & 44 \\
\hline 24 & $\mathrm{~F}$ & 49 \\
\hline 25 & $F$ & 50 \\
\hline 26 & $\mathrm{M}$ & 42 \\
\hline 27 & $\mathrm{M}$ & 47 \\
\hline 28 & $\mathrm{~F}$ & 53 \\
\hline 29 & $\mathrm{M}$ & 52 \\
\hline 30 & $F$ & 55 \\
\hline 31 & $\mathrm{~F}$ & 47 \\
\hline 32 & $\mathrm{~F}$ & 50 \\
\hline 33 & $\mathrm{M}$ & 50 \\
\hline 34 & $\mathrm{M}$ & 45 \\
\hline 35 & F & 47 \\
\hline 36 & $\mathrm{~F}$ & 52 \\
\hline 37 & $\mathrm{M}$ & 43 \\
\hline 38 & $\mathrm{M}$ & 42 \\
\hline 39 & $\mathrm{~F}$ & 53 \\
\hline 40 & $\mathrm{M}$ & 56 \\
\hline 41 & $\mathrm{~F}$ & 54 \\
\hline 42 & $\mathrm{~F}$ & 46 \\
\hline 43 & $\mathrm{M}$ & 48 \\
\hline 44 & $F$ & 56 \\
\hline 45 & $F$ & 48 \\
\hline 46 & $\mathrm{~F}$ & 46 \\
\hline 47 & $\mathrm{M}$ & 47 \\
\hline 48 & $\mathrm{M}$ & 38 \\
\hline 49 & $\mathrm{M}$ & 48 \\
\hline 50 & $\mathrm{~F}$ & 55 \\
\hline 51 & $\mathrm{M}$ & 42 \\
\hline 52 & $\mathrm{M}$ & 50 \\
\hline
\end{tabular}

Average Score: 48.86

Highest Score: 60

Lowest Score: 38 
Male Students Response:

\begin{tabular}{|l|l|}
\hline SCORES & NUMBER OF STUDENTS \\
\hline Unhealthy Family Environment Score & 0 \\
\hline Moderate Family Environment Score & 13 \\
\hline Healthy Family Environment Score & 10 \\
\hline
\end{tabular}

Male highest Score: 57

Male Lowest Score: 38

Female Students Response :

\begin{tabular}{|l|l|}
\hline SCORES & NUMBER OF STUDENTS \\
\hline Unhealthy Family Environment Score & 0 \\
\hline Moderate Family Environment Score & 9 \\
\hline Healthy Family Environment Score & 20 \\
\hline
\end{tabular}

Female Highest Score: 60

Female Lowest Score: 40

\begin{tabular}{|l|l|l|l|l|}
\hline & overall & $\begin{array}{l}\text { Unhealthy } \\
{[\text { 20-33] }}\end{array}$ & $\begin{array}{l}\text { Moderate } \\
{[\text { 34-47] }}\end{array}$ & $\begin{array}{l}\text { Healthy } \\
{[\text { 48-60] }}\end{array}$ \\
\hline Average score & 48.86 & 0 & 44 & 52.43 \\
\hline $\begin{array}{l}\text { Number of } \\
\text { students }\end{array}$ & 52 & 0 & 22 & 30 \\
\hline High score & 60 & 0 & 47 & 60 \\
\hline Low score & 38 & 0 & 38 & 48 \\
\hline
\end{tabular}

\section{Average Score Of Male And Female}

\begin{tabular}{|l|l|}
\hline GENDER & AVERAGE SCORE \\
\hline Male & 47.21 \\
\hline Female & 50.17 \\
\hline
\end{tabular}

\section{Average Score Of Each Category}

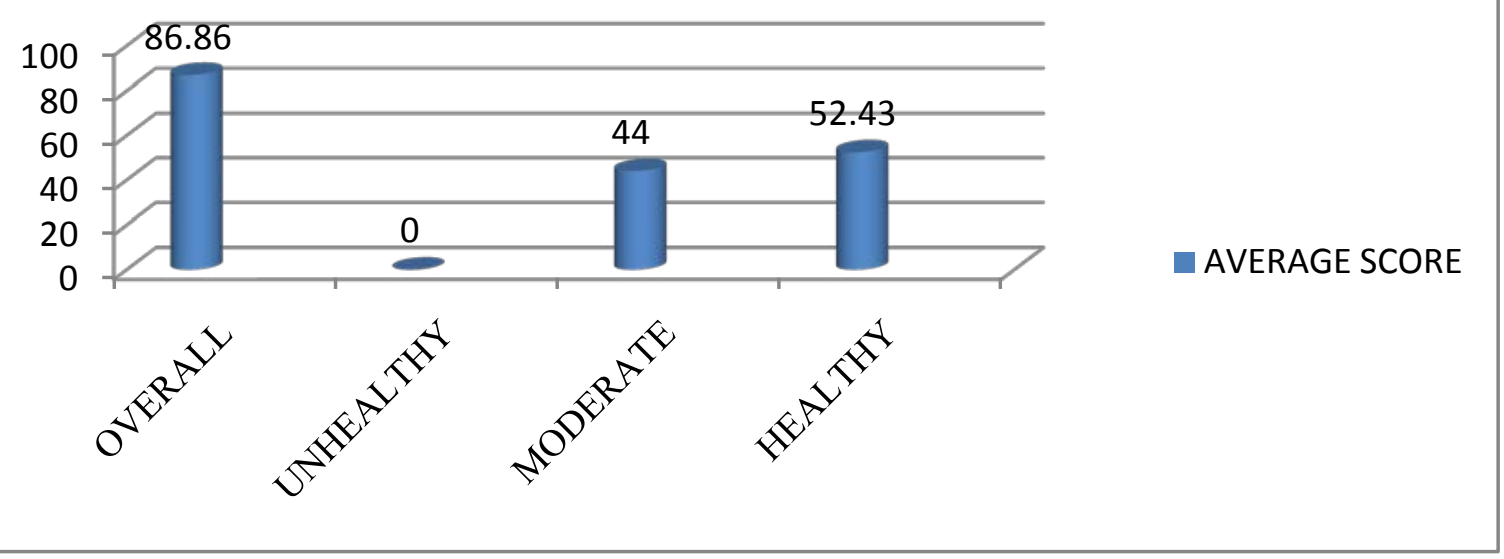


Number Of Students In Each Category

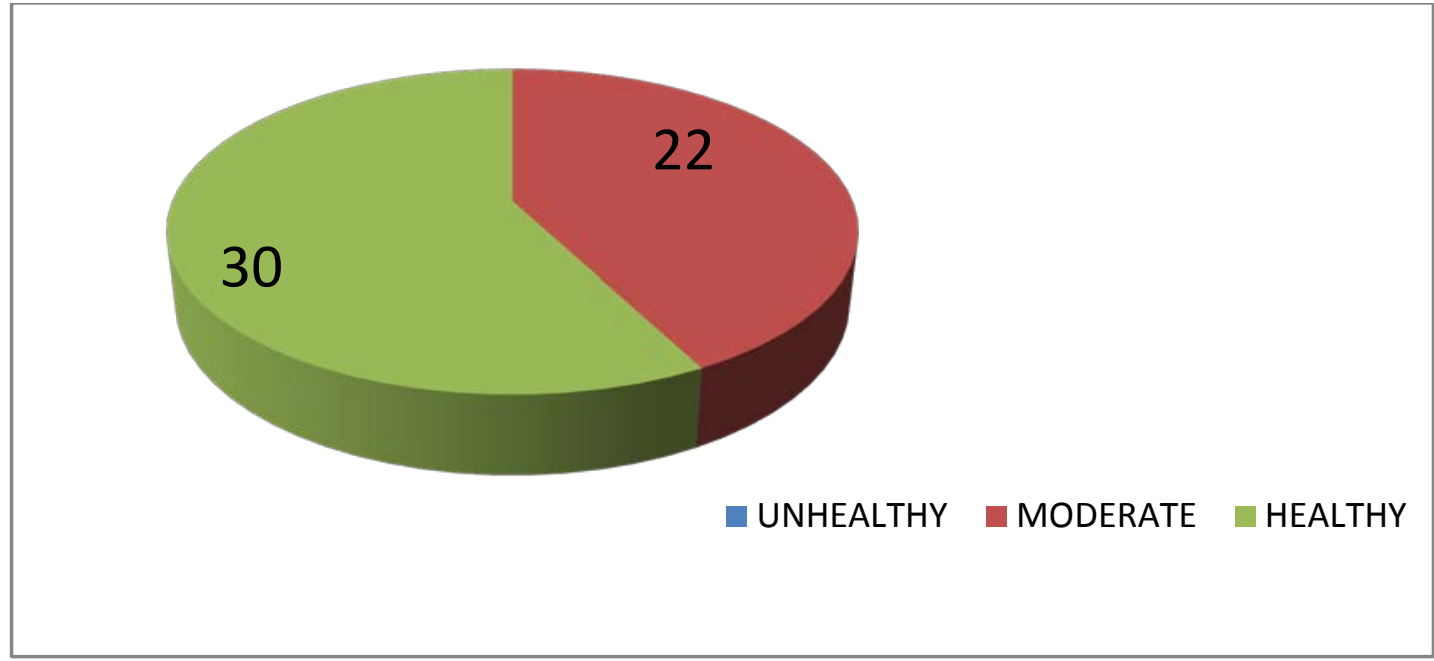

Number Of Male And Female Students In Each Category

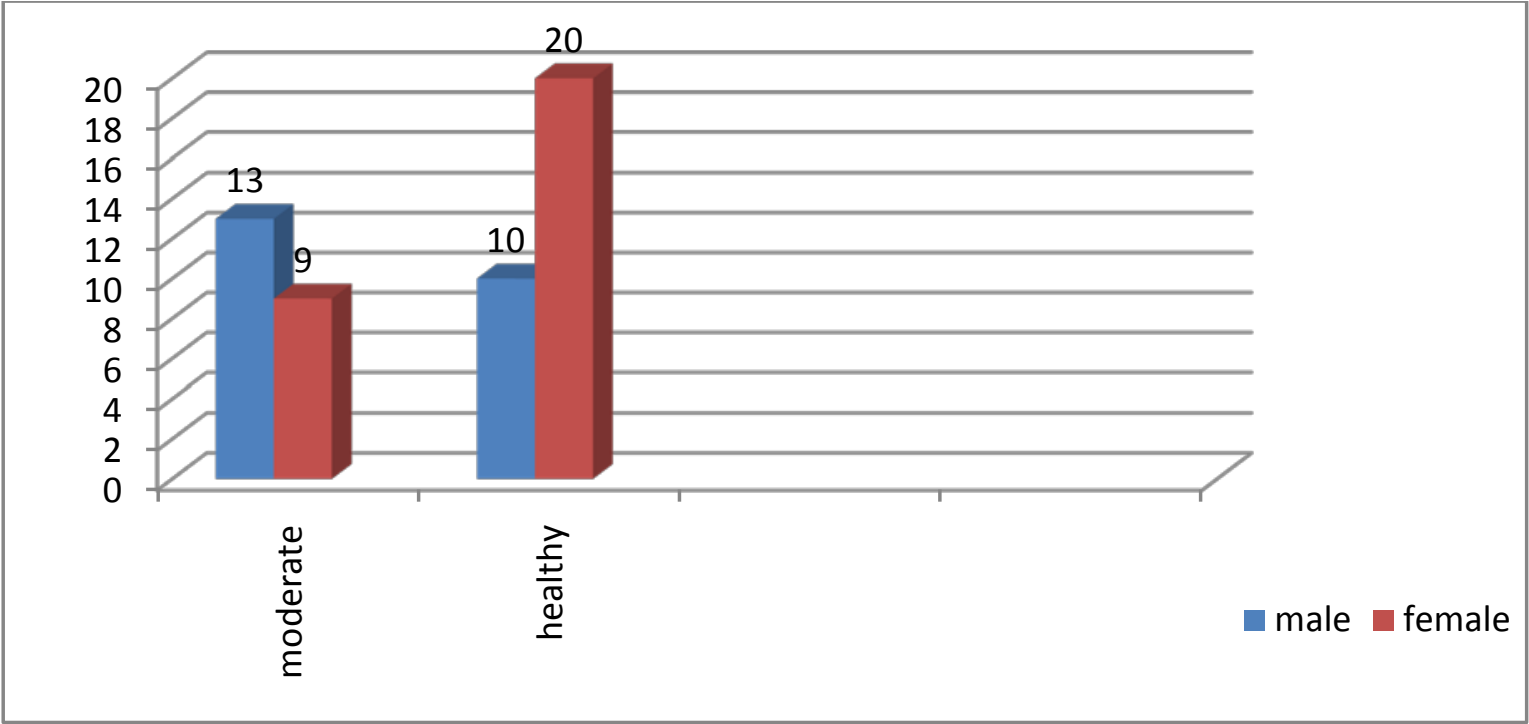

\section{DISCUSSION}

In the results, family environment of students is divided into three categories based upon their family environment score as unhealthy, moderate, healthy family environment. In overall dimensions, the average value of students' family environment is found to be 48.86, which falls under healthy family environment category. The average value of the students' family environment which fall under unhealthy family environment is 0 whereas the average value of students family environment which falls under moderate family environment is 44 and the average of students family environment which falls under healthy family environment is 52.43 . From the chart, it is clear that number of healthy family environment students is 30 which is more than the number of moderate family environment students while number of unhealthy 


\section{Measurement of Family Environment Levels among Students of Saveetha Dental College: Questionnaire Based Study}

family environment students is 0 . This shows that the students have moderate and healthy family environment. From the results, it is clear that the high and low score of the students' moderate family environment are 47 and 38 respectively and the high and low score of the students' healthy family environment are 60 and 48. Number of female students in healthy family environment is more than the number of male students in healthy family environment. This shows that the female students enjoy the better family environment when compared to males.

\section{CONCLUSION}

Healthy family environment promotes satisfactions and security. Unhealthy family environment leads to maladjustment delinquent behavior and anxiety. It also creates inferiority complex in students. It lowers their motivation levels which in turn affects the educational achievement of these students.(2) Students in healthy family environment should try to persist in this healthy family environment level. Students in moderate family environment can be given psychological counseling sessions in order to better their self -concept and the parents should be made to realize that their attitude towards children plays an important role in he child's behavior. Individuals differ in their family environment.

\section{REFERENCES}

1. AmitKauts, Balwinder Kaur. Study of children's behavior in relation to family environment and technological exposure at pre primary stage.

2. Deepishikha, Suman Bhanot. Role of family environment on socio emotional adjustment of adolescent girls in rural areas of eastern Uttar Pradesh- India J psychology 2(1): 53-56 (2011).

3. Dr. Punam Devi Bagi, Manojkumar- Relationship between family environment and well being: A study of Adolescents- International journal of informative and futuristic research volume 2 issue 1 September 2014.

4. Gargi Sharma, Kumud Pandav, Sukhjot KaurLally. Role of family environment on adolescent well being- International journal of recent scientific research.

5. KrishanLal,- Impact of family relationship of B.Ed students on their adjustment American international journal of research in humanities, arts and social sciences, 5(1), December 2014- February 2014.

6. Rashmikant N. Parmar. A study of various dimensions of home environment among higher secondary school students in relation to gender- International journal for technological research in engineering vol. 1, issue 7, march 2014.

7. Ravinderkumar,- Impact of family relationship of B.Ed students on their adjustment - An international journal-139. Vol XIV (8) October 2015.

8. Supninder Kaur, Mini Sapra. Correlation study of depression, family environment and self concept among adolescents-International journal of psychological science vol5.

How to cite this article: K Harini, K Krishnamoorthy (2016), Measurement of Family Environment Levels among Students of Saveetha Dental College: Questionnaire Based Study, International Journal of Indian Psychology, Volume 3, Issue 3, No. 7, DIP: 18.01.128/20160303, ISBN: 978-1-365-12175-3 